\title{
Kewenangan Khusus Majelis Rakyat Papua Terhadap Pembentukan Perdasus
}

\author{
A. Sakti R.S. Rakia \\ Fakultas Hukum, Universitas Muhammadiyah Sorong \\ Email : Ramdhansyah44@gmail.com
}

\begin{abstract}
This study aims to analyze the regulation of special powers and the position of the Papuan People's Assembly (MRP) in the formation of the Special Regional Regulations (Perdasus). The method used in this research is juridical normative research with a statute approach, which is analyzed qualitatively. The results of this study indicate that based on the Papua Special Autonomy Law, the MRP institution only has certain powers in the framework of protecting the rights of indigenous Papuans based on respect for customs and culture, empowering women, and strengthening religious harmony. In other words, the MRP does not have pure authority in the field of legislation, because based on Article 20 paragraph (1) letter $c$, the MRP only provides consideration and approval of the Draft Perdasus submitted by the DPRP and the Governor.
\end{abstract}

Keywords: Papuan People's Council, Special Regional Regulations, Special Autonomy Perdasus Papua.

\begin{abstract}
Abstrak
Penelitian ini bertujuan untuk menganalisis mengenai pengaturan tentang kewenangan khusus serta kedudukan Majelis Rakyat Papua (MRP) dalam pembentukan Peraturan Daerah Khusus (Perdasus). Metode yang digunakan dalam penelitian ini adalah penelitian normatif yuridis dengan pendekatan statute approach, yang dianalisis secara kualitatif. Hasil penelitian ini menunjukan bahwa berdasarkan UU Otsus Papua, lembaga MRP hanya memiliki kewenangan tertentu dalam rangka perlindungan hak-hak orang asli Papua dengan berlandaskan pada penghormatan terhadap adat dan budaya, pemberdayaan perempuan, dan pemantapan kerukunan hidup beragama. Dengan kata lain, MRP tidak memiliki kewenangan murni di bidang legislasi, sebab berdasarkan Pasal 20 ayat (1) huruf c, MRP hanya memberikan pertimbangan dan persetujuan terhadap Rancangan Perdasus yang diajukan oleh DPRP dan Gubernur.
\end{abstract}


Kata Kunci : Majelis Rakyat Papua, Peraturan Daerah Khusus, Perdasus Otonomi Khusus Papua.

\section{PENDAHULUAN}

Keberadaan Peraturan Daerah Khusus (selanjutnya disebut Perdasus) pada prinsipnya memiliki peran krusial sebagai salah satu wujud penyelenggaraan pemerintahan daerah Papua (dan Papua Barat) berdasarkan kewenangan otonomi khusus. Fungsi dari Perdasus sendiri sebagaimana tertuang dalam Undang-Undang Nomor 21 Tahun 2001 jo. Perpu No. 1 tahun 2008 jo. Undang-Undang Nomor 35 Tahun 2008 (selanjutnya disebut UU Otsus), adalah untuk melaksanakan Pasal-Pasal tertentu dalam UU Otsus. Berdasarkan Pasal 29 UU Otsus, Perdasus dibuat dan ditetapkan oleh Dewan Perwakilan Rakyat Papua (DPRP) bersama-sama Gubernur dengan pertimbangan dan persetujuan Majelis Rakyat Papua (MRP). Berbeda dengan Perdasus, Peraturan Daerah Provinsi (Perdasi) dibuat dan ditetapkan oleh DPRP dan Gubernur, tanpa persetujuan MRP.

Kedudukan MRP dalam penyelenggaraan pemerintahan daerah dengan kewenangan khusus berdasarkan Pasal 1 huruf g UU Otsus, adalah sebagai representasi kultural orang asli Papua, yang memiliki wewenang tertentu dalam rangka perlindungan hak-hak orang asli Papua dengan berlandaskan pada penghormatan terhadap adat dan budaya, pemberdayaan perempuan, dan pemantapan kerukunan hidup beragama.

Selain dari pada itu, Salah satu bentuk kewenangan khusus yang dimiliki oleh MRP yakni memberi pertimbangan dan persetujuan terhadap rancangan Perdasus hasil pembahasan antara Dewan Perwakilan Rakyat Papua (DPRP) dan Gubernur. Tata cara pemberian pertimbangan dan persetujuan MRP terhadap Perdasus dituangkan dalam Pasal 38 PP Nomor 54 tahun 2004 tentang Majelis Rakyat Papua, jo. Pasal 8-13 Perdasus Nomor 4 Tahun 2008 tentang Pelaksanaan Tugas Dan Wewenang Majelis Rakyat Papua.

Sekalipun demikian, kewenangan dalam memberikan pertimbangan dan persetujuan yang dimiliki MRP tidak dapat disebut sebagai kewenangan legislasi, sebab, sebagaimana tertuang dalam Pasal 6 ayat (1), kekuasaan legislasi dilaksanakan oleh DPRP. Keberadaan kewenangan khusus MRP dalam memberikan pertimbangan dan persetujuan terhadap Perdasus, tidak 
dilengkapi dengan hak untuk meminta peninjauan kembali atas Perdasus. Hal ini berbeda dengan Pasal 21 ayat (1) huruf $b$ menyebutkan bahwa MRP berhak meminta peninjauan kembali atas Perdasi atau Keputusan Gubernur yang dinilai bertentangan dengan perlindungan hak-hak orang asli Papua.

Beberapa kewenangan yang dimiliki oleh MRP sebagaimana tertuang dalam sejumlah Peraturan Perundang-Undangan apabila dicermati dari segi kedudukannya, mencerminkan inti dari urgensi dan tujuan dibentuknya UU Otsus. Sebagai lembaga representatif kultural orang asli Papua di beberapa bidang dan dengan sejumlah hak, tugas dan wewenang, menempatkan kedudukan MPR sebagai sebuah lembaga yang istimewa dalam penyelenggaraan pemerintahan daerah berdasarkan kewenangan otonomi khusus. Akan tetapi, sebagaimana diuraikan diatas, tidak adanya kewenangan MRP dalam melakukan peninjauan terhadap Perdasus merupakan masalah yang unik sehingga menarik untuk diteliti.

\section{PEMBAHASAN}

\section{Tinjauan Umum Mengenai Otonomi Khusus Papua}

Dasar konstitusional pelaksanaan otonomi daerah di Indonesia merujuk pada Pasal 18 UUD NRI 1945 yang dilaksanakan berdasarkan asas otonomi dan tugas pembantuan. Dalam Undang-Undang Nomor 23 Tahun 2014 tentang Pemerintahan Daerah, sebagaimana telah diubah dengan Undang-Undang Nomor 9 tahun 2015 tentang Perubahan Kedua Atas Undang-Undang Nomor 23 Tahun 2014 tentang Pemerintahan Daerah (selanjutnya disebut UU Pemda), disebutkan bahwa otonomi daerah Otonomi Daerah adalah hak, wewenang, dan kewajiban daerah otonom untuk mengatur dan mengurus sendiri Urusan Pemerintahan dan kepentingan masyarakat setempat dalam sistem Negara Kesatuan Republik Indonesia. Sedangkan Tugas Pembantuan adalah penugasan dari Pemerintah Pusat kepada daerah otonom untuk melaksanakan sebagian Urusan Pemerintahan yang menjadi kewenangan Pemerintah Pusat atau dari Pemerintah Daerah provinsi kepada Daerah kabupaten/kota untuk melaksanakan sebagian Urusan Pemerintahan yang menjadi kewenangan Daerah provinsi.

Provinsi Papua sebagai salah satu daerah otonom di Indonesia memiliki kekhasan tersendiri dalam penyelenggaraan pemerintahan daerahnya. Berdasarkan UU Otsus, disebutkan 
bahwa Provinsi Papua adalah Provinsi Irian Jaya yang diberi Otonomi Khusus dalam kerangka Negara Kesatuan Republik Indonesia, yakni kewenangan khusus yang diakui dan diberikan kepada Provinsi Papua untuk mengatur dan mengurus kepentingan masyarakat setempat menurut prakarsa sendiri berdasarkan aspirasi dan hak-hak dasar masyarakat Papua.

Dalam Penjelasan UU Otsus, hal-hal mendasar yang diatur dalam otonomi khusus Papua menyangkut beberapa aspek, yaitu, Pertama, pengaturan kewenangan antara Pemerintah dengan Pemerintah Provinsi Papua serta penerapan kewenangan tersebut di Provinsi Papua yang dilakukan dengan kekhususan. Kedua, pengakuan dan penghormatan hak-hak dasar orang asli Papua serta pemberdayaannya secara strategis dan mendasar. Ketiga, mewujudkan penyelenggaraan pemerintahan yang baik yang berciri :

a. partisipasi rakyat sebesar-besarnya dalam perencanaan, pelaksanaan dan pengawasan dalam penyelenggaraan pemerintahan serta pelaksanaan pembangunan melalui keikutsertaan para wakil adat, agama, dan kaum perempuan;

b. pelaksanaan pembangunan yang diarahkan sebesar-besarnya untuk memenuhi kebutuhan dasar penduduk asli Papua pada khususnya dan penduduk Provinsi Papua pada umumnya dengan berpegang teguh pada prinsip-prinsip pelestarian lingkungan, pembangunan berkelanjutan, berkeadilan dan bermanfaat langsung bagi masyarakat; dan

c. penyelenggaraan pemerintahan dan pelaksanaan pembangunan yang transparan dan bertanggungjawab kepada masyarakat.

Keempat, pembagian wewenang, tugas, dan tanggung jawab yang tegas dan jelas antara badan legislatif, eksekutif, dan yudikatif, serta Majelis Rakyat Papua sebagai representasi kultural penduduk asli Papua yang diberikan kewenangan tertentu.

Dalam perkembangannya daerah Papua berkembang menjadi 2 (dua), yakni Provinsi Papua dan Papua Barat yang terbentuk berdasarkan Perpu Nomor 1 tahun 2008, sebagaimana telah ditetapkan menjadi Undang-Undang Nomor 35 tahun 2008. Disebutkan dalam konsideran UU Nomor 35 Tahun 2008, pemberlakuan otonomi khusus bagi Provinsi Papua Barat memerlukan kepastian hukum yang sifatnya mendesak dan segera agar tidak menimbulkan hambatan percepatan pembangunan khususnya bidang sosial, ekonomi, dan politik serta infrastruktur di 
Provinsi Papua Barat. Peraturan inilah yang dijadikan sebagai dasar pelaksanaan otonomi khusus baik di provinsi Papua maupun Provinsi Papua Barat.

Pengaturan kewenangan antara Pemerintah dengan Pemerintah Provinsi Papua serta penerapan kewenangan tersebut di Provinsi Papua yang dilakukan dengan kekhususan tertuang dalam Pasal 4 UU Otsus. Disebutkan dalam Pasal tersebut bahwa Kewenangan Provinsi Papua mencakup kewenangan dalam seluruh bidang pemerintahan, kecuali kewenangan bidang politik luar negeri, pertahanan keamanan, moneter dan fiskal, agama, dan peradilan serta kewenangan tertentu di bidang lain yang ditetapkan sesuai dengan peraturan perundang-undangan. Selain itu dalam JUSTISI 201927 rangka pelaksanaan Otonomi Khusus, Provinsi Papua diberikan kewenangan khusus berdasarkan UU Otsus yang diatur lebh lanjut dengan Perdasus dan Perdasi. Daerah Kabupaten/Kota mencakup pula kewenangan sebagaimana telah diatur dalam peraturan perundang-undangan, disamping juga kewenangan khusus berdasarkan UU Otsus yang diatur pula dalam Perdasus dan Perdasi.

\section{Majelis Rakyat Papua}

Salah satu bentuk kekhususan Provinsi Papua yakni keberadaan Majelis Rakyat Papua. Dalam UU Otsus, disebutkan bahwa MRP adalah representasi kultural orang asli Papua, yang memiliki wewenang tertentu dalam rangka perlindungan hak-hak orang asli Papua dengan berlandaskan pada penghormatan terhadap adat dan budaya, pemberdayaan perempuan, dan pemantapan kerukunan hidup beragama sebagaimana diatur dalam UU Otsus. Berdasarkan Pasal 19 ayat (1) UU Otsus, MRP mempunyai tugas dan wewenang untuk :

a. memberikan pertimbangan dan persetujuan terhadap bakal calon Gubernur dan Wakil Gubernur yang diusulkan oleh DPRP;

b. memberikan pertimbangan dan persetujuan terhadap calon anggota Majelis Permusyawaratan Rakyat Republik Indonesia utusan daerah Provinsi Papua yang diusulkan oleh DPRP;

c. memberikan pertimbangan dan persetujuan terhadap Rancangan Perdasus yang diajukan oleh DPRP bersama-sama dengan Gubernur;

d. memberikan saran, pertimbangan dan persetujuan terhadap rencana perjanjian kerjasama yang dibuat oleh Pemerintah maupun Pemerintah Provinsi dengan pihak 
ketiga yang berlaku di Provinsi Papua khusus yang menyangkut perlindungan hak-hak orang asli Papua;

e. memperhatikan dan menyalurkan aspirasi, pengaduan masyarakat adat, umat beragama, kaum perempuan dan masyarakat pada umumnya yang menyangkut hak-hak orang asli Papua, serta memfasilitasi tindak lanjut penyelesaiannya; dan

f. memberikan pertimbangan kepada DPRP, Gubernur, DPRD Kabupaten/Kota serta Bupati/Walikota mengenai hal-hal yang terkait dengan perlindungan hak-hak orang asli Papua.

Pelaksanaan tugas dan wewenang MRP secara lebih rinci selanjutnya diatur dalam Peraturan Daerah khusus (Perdasus). MRP juga memiliki hak-hak yang terdiri dari hak secara kelembagaan dan hak keanggotaan. Hak lembaga MRP meliputi :

a. meminta keterangan kepada Pemerintah Provinsi, Kabupaten/Kota mengenai hal-hal yang terkait dengan perlindungan hak-hak orang asli Papua;

b. meminta peninjauan kembali Perdasi atau Keputusan Gubernur yang dinilai bertentangan dengan perlindungan hak-hak orang asli Papua;

c. mengajukan rencana Anggaran Belanja MRP kepada DPRP sebagai satu kesatuan dengan Anggaran Pendapatan dan Belanja Daerah Provinsi Papua; dan

d. menetapkan Peraturan Tata Tertib MRP.

Sementara itu, hak anggota MRP terdiri dari :
a. mengajukan pertanyaan;
b. menyampaikan usul dan pendapat;
c. imunitas;
d. protokoler; dan
e. keuangan/administrasi.

Berkaitan dengan hak-hak MRP baik hak kelembagaan maupun hak keanggotaan apabila diperhatikan pada dasarnya memiliki kesamaan dengan hak-hak lembaga legislatif pada umumnya. Hanya saja dalam UU Otsus belum diatur secara tegas mengenai hak MRP dalam melakukan angket terhadap pemerintah. Kalau diperhatikan secara lebih teliti, pada dasarnya 
tidak ada ketentuan yang secara tegas menjelaskan apakah MRP merupakan lembaga legislatif daerah, ataukah hanya sebuah lembaga representasi kultural OAP. Secara umum, peraturan yang dapat dibentuk oleh MRP yang bersifat mengikat ke luar belum tegas sebagai cerminan lembaga legislatif daerah pada umumnya.

\section{Peraturan Daerah Khusus (Perdasus)}

Dasar konstitusionalitas pembentukan peraturan-peraturan di daerah merujuk pada Pasal 18 ayat (6) UUD NRI 1945, yakni "Pemerintahan daerah berhak menetapkan peraturan daerah dan peraturan-peraturan lain untuk melaksanakan otonomi dan tugas pembantuan". Frasa "dan peraturan-peraturan lainnya" dalam Pasal 18 ayat (6) UUD NRI 1945 ini memberikan atribusi kewenangan kepada pemerintahan daerah untuk membentuk peraturan lainnya selain Peraturan Daerah (Perda), yang jenis dan bentuknya disesuaikan dengan istilah-istilah beragam di tingkat Provinsi maupun Kabupaten/Kota.

Berdasarkan Pasal 1 huruf I UU Otsus, Peraturan Daerah Khusus (Perdasus) Peraturan Daerah Provinsi Papua dalam rangka pelaksanaan pasal-pasal tertentu dalam UU Otsus. Hal ini juga tertuang dalam Permendagri Pasal Nomor 120 Tahun 2018, disebutkan bahwa Perda Khusus yang disingkat Perdasus, adalah Perda Provinsi Papua dan Provinsi Papua Barat dalam rangka pelaksanaan pasal tertentu dalam Undang-Undang Otonomi Khusus bagi Papua dan Papua Barat. Sedikitnya terdapat 14 (empat belas) ketentuan dalam UU Otsus yang secara tegas memerintahkan agar beberapa hal dalam UU Otsus. Pasal-Pasal tersebut terdiri dari, Pasal 2 ayat (3); Pasal 4 ayat (3); Pasal 4 ayat (5); Pasal 4 ayat (9); Pasal 11 ayat (3); Pasal 19 ayat (3); Pasal 20 ayat (2); Pasal 21 ayat ayat (2); Pasal 23 ayat (2); Pasal 34 ayat (3) huruf c; Pasal 38 ayat (2); Pasal 66 ayat (2); Pasal 67 ayat (2); dan Pasal 71 ayat (2).

Mekanisme pembentukan peraturan di daerah pada dasarnya tunduk pada ketentuan Undang-Undang Nomor 12 tahun 2011, sebagaimana telah diubah dengan Undang-Undang Nomor 15 Tahun 2019 tentang Perubahan Atas Undang-Undang Nomor 12 tahun 2011. Namun pelaksanaan teknis pembentukan Perdasus maupun Perdasi diatur dalam Peraturan DPRP Nomor 1 tahun 2014 tentang Tata Tertib. Adapun mekanisme pembentukan Perdasus maupun Perdasi dapat dilihat dalam bagan sebagai berikut : 


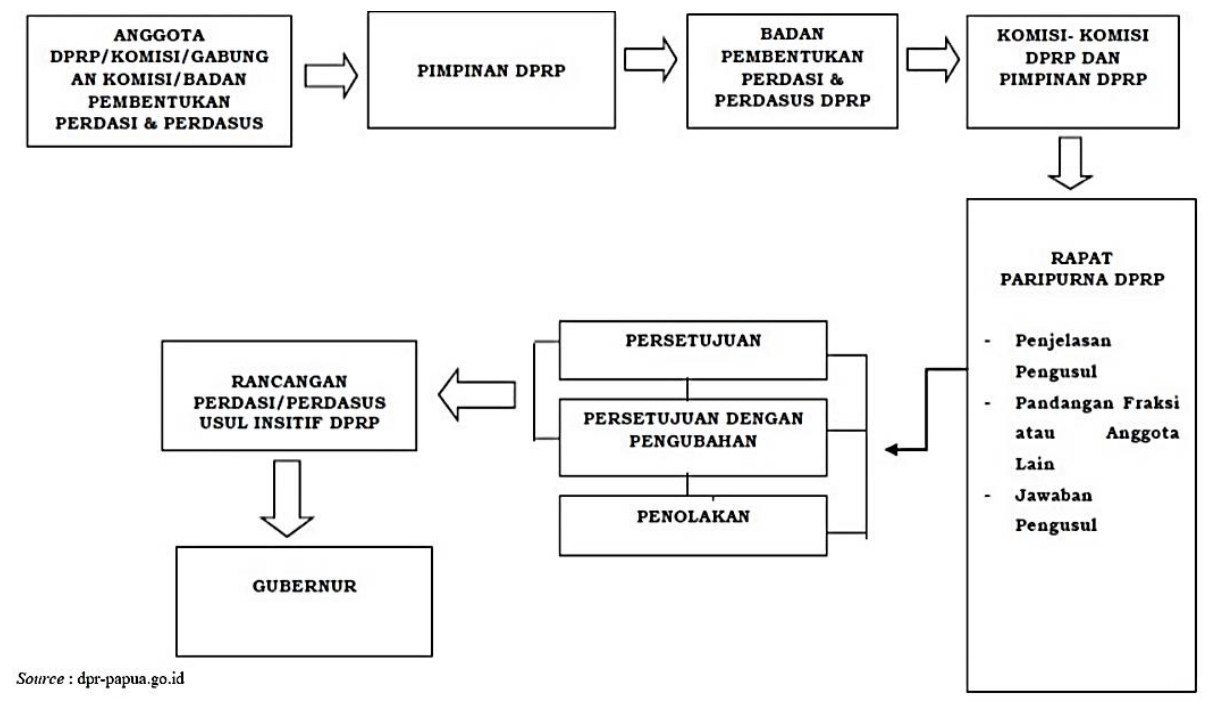

Gambar 2.1 : Mekanisme Pembentukan Raperdasi/Raperdasus Inisiatif DPR Papua

Adapun mekanisme pembahasan Raperdasus maupun Raperdasi berdasarkan Pasal 109 Tatib DPR Papua, dibagi ke dalam mekanisme usulan DPR Papua dan eksekutif. Mekanisme pembahasan atas usulan DPR Papua diuraikan dalam alur bagan sebagai berikut :
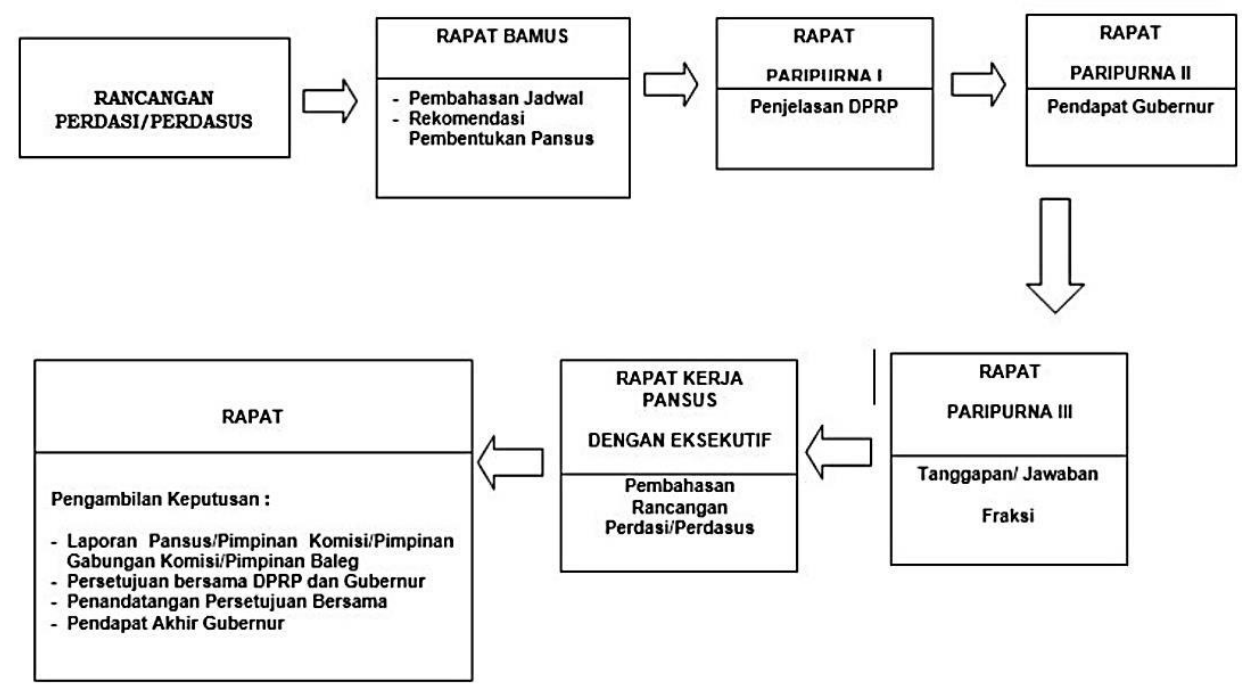

Source : dpr-papua.go.id

Gambar 2.2 : Mekanisme Pembahasan Raperdasi/Raperdasus Inisiatif DPR Papua 
Mekanisme pembahasan atas usulan eksekutif adalah sebagai berikut :

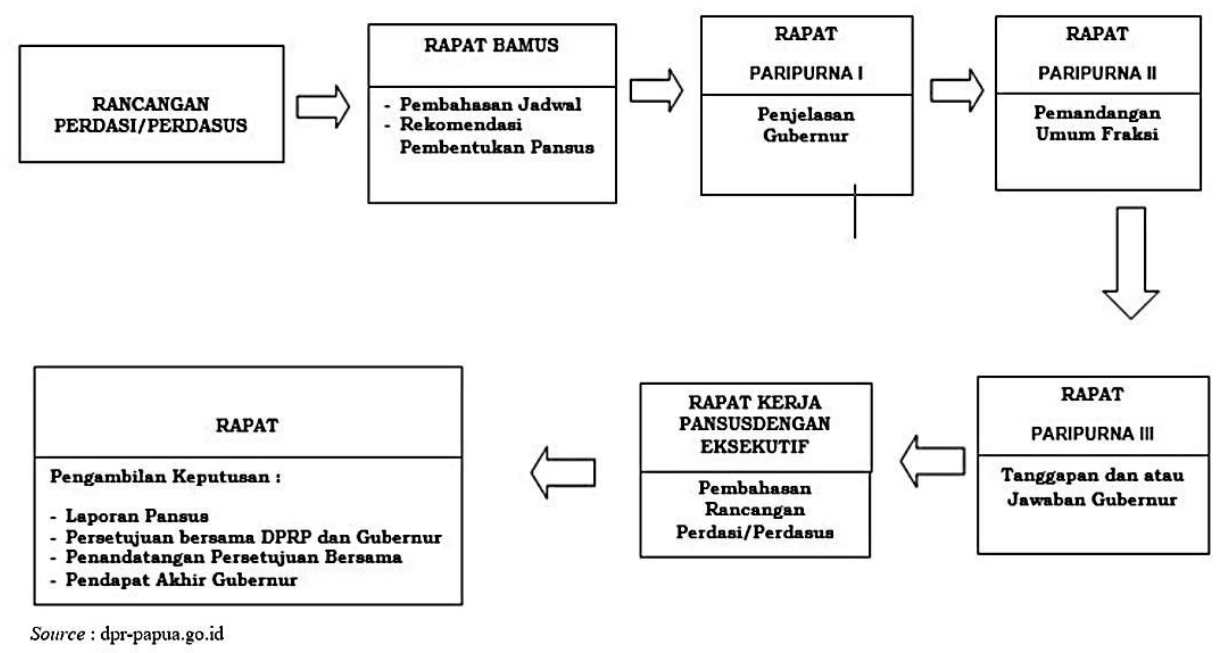

Gambar 2.3 : Mekanisme Pembahasan Raperdasi/Raperdasus Inisiatif DPR Papua

\section{Kewenangan Khusus Majelis Rakyat Papua dalam Pembentukan Perdasus}

Sebagaimana telah diuraikan sebelumnya bahwa salah satu kewenangan yang dimiliki oleh Majelis Rakyat papua (MRP) dalam kaitannya dengan pembentukan Perdasus, yakni memberikan pertimbangan dan persetujuan terhadap Rancangan Perdasus yang diajukan oleh DPRP bersama-sama dengan Gubernur. Apabila diperhatikan ketentuan-ketentuan dalam UU Otsus yang memberikan delegasi kewenangan kepada pemerintahan daerah Papua, merupakan inti dari pelaksanaan otonomi khusus daerah Papua, sebagaimana diuraikan dalam konsideran menimbang dan Penjelasan UU Otsus. Keberadaan ketentuan-ketentuan dalam UU Otsus yang selanjutnya diatur dengan Perdasus merupakan cerminan politik hukum pemerintah pusat dalam memberikan kewenangan pemerintah daerah Papua yang berbeda dengan sebagian besar pemerintahan daerah pada umumnya di Indonesia.

Ketidakjelasan norma UU Otsus dalam menjelaskan kedudukan MRP berdampak pada kedudukan dan tupoksi MRP sendiri sebagai lembaga representasi kultural OAP. Sebagai sebuah lembaga representasi OAP, keberadaan MRP dinilai lebih mencerminkan aspirasi-aspirasi masyarakat Papua pada umumnya. Hal ini dapat dilihat melalui komposisi pengaturan lembaga MRP baik dari proses rekruitment, alat kelengkapan, serta kewenangan-kewenangan lainnya. Kedudukan MRP yang tidak dijelaskan secara tegas dalam fungsi kerjanya terutama dalam 
pembentukan Perdasus apabila dipandang dari segi pendekatan teori lembaga legislatif pada hakikatnya tidak tercermin secara maksimal sebagai sebuah lembaga legislatif.

Kalau diperhatikan, mekanisme pembentukan dan pembahasan Perdasus dalam Tatib DPRP, peran atau kontribusi serta keterlibatan MRP sangat minim sebab hanya memberikan pertimbangan dan persetujuan terhadap Raperdasus. Disisi lain sebagaimana diketahui bersama bahwa proses pembentukan peraturan merupakan sebuah proses politik yang melibatkan sejumlah kelompok-kelompok politik dengan kepentingan masing-masing. Minimnya keterlibatan MRP dalam pembentukan Perdasus sebagai seperangkat aturan yang menerima atribusi dari UU Otsus, berpotensi mengecilkan realitas dan aspirasi politik masyarakat Papua yang direpresentasikan oleh MRP.

Dalam kajian pembentukan peraturan terdapat pemikiran bahwa manakala suatu aturan dinilai tidak memadai, atau bahkan tidak mencerminkan politik hukum tertentu yang menjadi dasar pembentukan peraturan, maka peraturan tersebut sewaktu-waktu boleh diubah, dicabut, atau ditinjau kembali. Akan tetapi kewenangan ini tidak dimiliki oleh MRP, sebab dalam Pasal 21 ayat (1) huruf b UU Otsus, MRP hanya dapat meminta peninjauan kembali terhadap Perdasi, bukan Perdasus. Selain itu, MRP hanya memiliki kewenangan yang berkaitan dengan meminta keterangan kepada eksekutif, namun tidak memiliki wewenang untuk melakukan penyelidikan terhadap kebijakan pemerintah yang dianggap tidak sesuai dengan UU Otsus.

Minimnya keterlibatan MRP dalam pembentukan Perdasus memberikan pertanyaan hukum mengenai kedudukan lembaga MRP, apakah harus dilihat sebagai sebuah lembaga legislatif daerah, ataukah hanya merupakan lembaga representatsi kultural OAP. Apabila MRP dipandang sebagai lembaga legislatif, maka bentuk dan sifat legislasi yang dimiliki oleh MRP sangat terbatas, dan untuk itu dapat disebut dengan lembaga semi legislatif. Disebut semi legislatif karena sebagai sebuah lembaga representasi, MRP tidak memiliki kewenangan-kewenangan sebagai sebuah lembaga legislatif daerah pada umumnya.

Dalam kajian mengenai parlemen, dikenal istilah upper house dan lower house. Apabila terdapat 2 (dua) lembaga pembentuk peraturan yang memiliki kewenangan yang sama kuat, maka disebut sebagai upper house. Hal ini tercermin dalam DPR dan Senat di Amerika yang keduanya memiliki kedudukan sama kuat, sehingga apabila rundingan politik antar kedua 
lembaga tersebut deadlock, maka akan diteruskan di kongres. Namun apabila terdapat 2 (dua) lembaga yang salah satunya memiliki kewenangan yang lebih kuat, maka disebut sebagai lower house. Apabila dibandingkan antara MRP dan DPRP dalam hal pembentukan Perdasus, maka akan mencerminkan realitas lembaga lower house sebab kewenangan MRP dalam pembentukan Perdasus sebagaimana tertuang dalam UU Otsus maupun Tatib DPRP sangat terbatas.

\section{SIMPULAN}

Berdasarkan apa yang telah diuraikan sebelumnya maka dapat diketahui bahwa, lembaga MRP hanya memiliki kewenangan tertentu dalam rangka perlindungan hak-hak orang asli Papua dengan berlandaskan pada penghormatan terhadap adat dan budaya, pemberdayaan perempuan, dan pemantapan kerukunan hidup beragama. Dengan kata lain, MRP tidak memiliki kewenangan murni di bidang legislasi, sebab berdasarkan Pasal 20 ayat (1) huruf c, MRP hanya memberikan pertimbangan dan persetujuan terhadap Rancangan Perdasus yang diajukan oleh DPRP dan Gubernur. Tidak ada pasal maupun penjelasan yang secara tegas menguraikan tentang kedudukan lembaga Majelis Rakyat Papua sebagai representasi kultural orang asli Papua (OAP), apakah lembaga MRP bersifat legislatif, semi legislatif, ataupun bukan lembaga legislatif

\section{REFERENSI}

A. Sakti Ramdhon Syah R., 2019, Penerapan Pasal 1 Huruf B Undang-Undang Nomor 35 Tahun 2008 Terhadap Penyelenggaraan Pemerintahan Daerah Provinsi Papua Barat, JUSTISI, Vol. 1, No. 3. DOI : https://doi.org/10.33506/js.v5i1.521

Bernarda Meteray, 2016, Dinamika Orang Papua Dalam Nieuw Guinea Raad (NGR) 1961 Dan Majelis Rakyat Papua (MRP) 2005 Di Tanah Papua, Masyarakat Indonesia : Jurnal Ilmu-Ilmu Sosial Indonesia, Vol. 42, No.1. DOI : https://doi.org/10.14203/jmi.v42i1.353

Haryanto, Cornelis Lay, Bambang Purwoko, 2018, Asymmetrical Decentralization, Representation, and Legitimacy in Indonesia: A Case Study of the Majelis Rakyat Papua, Asian Survey, Vol.8, No. 2, DOI : https://doi.org/10.1525/as.2018.58.2.365

Nelwan Ronsumbre, Dede Sri Kartini 2020, Perwakilan Masyarakat Adat Di Dewan Perwakilan Rakyat Papua: Dinamika Dan Relevansi Pembentukan Dengan Penguatan Demokrasi Deliberatif, Moderat: Jurnal Ilmiah Ilmu Pemerintahan, Vol 6, No.2. DOI : http://dx.doi.org/10.25157/moderat.v6i2.3400

Riris Katharina, 2017, Deliberative Formulation of Papua Special Autonomy Policy, International Journal of Administrative Science \& Organization, Bisnis \& 
Birokrasi: Jurnal Ilmu Administrasi dan Organisasi, Vol. 24, No. 2. DOI : https://10.20476/jbb.v24i2.9492

Ridwan HR, 2014, Hukum Administrasi Negara, cet. 11, Jakarta : Raja Grafindo Persada.

Rochendi S., Kausar Ali Saleh, 2017, Hubungan Pemerintah Pusat dan Daerah Dalam Otonomi Khusus Di Provinsi Papua Barat, Jurnal Kajian Politik Dan Masalah Pembangunan, Vol. 13 No. 1.

Yamin Rengen, 2017, Kelembagaan Majelis Rakyat Papua Barat (MRP-PB) Dalam Otonomi Khusus 2017, Journal of Governance And Public Policy, Vol. 4 No. 3.

Undang-Undang Nomor 21 Tahun 2001 tentang Otonomi Khusus bagi Provinsi Papua

Peraturan Pemerintah Nomor 1 tahun 2008 tentang Perubahan Atas Undang-Undang Nomor 21 Tahun 2001 Tentang Otonomi Khusus Bagi Provinsi Papua.

Undang-Undang nomor 35 Tahun 2008 tentang Penetapan Peraturan Pemerintah Pengganti Undang-Undang Nomor 1 Tahun 2008 Tentang Perubahan Atas Undang-Undang Nomor 21 Tahun 2001 Tentang Otonomi Khusus Bagi Provinsi Papua Menjadi Undang-Undang.

Peraturan Dewan Perwakilan rakyat Papua Nomor 01 Tahun 2014 Tentang Tentang Tata Tertib Dewan Perwakilan Rakyat Papua. 